\title{
ANALISIS KEPUASAN KONSUMEN TERHADAP KUALITAS PELAYANAN KLINIK ORTHOTIK PROSTHETIK KUSPITO JATEN KARANGANYAR
}

\author{
M. Syafi'i \\ Kementerian Kesehatan Politeknik Kesehatan Surakarta Jurusan Ortotik Prostetik
}

\begin{abstract}
The Balance, Arch Of The Foot. Clinic Orthotik Prosthetik Kuspito Karanganyar is a business organization engaged in health services facilities provided are of service in the manufacture of fake hands and feet (Orthotic Prosthetic). Orthotik clinic Prosthetik Kuspito is one of the few clinics in Indonesia. Large number of consumers who come to get service at the clinic Orthotik Prosthetik Kuspito, and its growing number of competitors particular region of Surakarta, the research is expected to know an idea of the quality of service making a false hand, artificial limbs and other mobility aids are offered Clinic Orthotik Prosthetik Kuspito and expectations and perceptions of consumers, and is expected to also obtain some information as input to the Clinic Orthotik Prosthetik Kuspito in order to improve the quality of care services to achieve customer satisfaction, increase consumer confidence, maintain and develop their businesses. The results of this study is to find out consumers' assessment of service quality and satisfaction that can be felt. This is important as a reference in order to service providing optimum satisfaction.
\end{abstract}

Keywords: Clinic Orthotic Prosthetic, Service Quality, Consumer Satisfaction

Abstrak: Keseimbangan, Lengkungan Kaki. Klinik Orthotik Prosthetik Kuspito Jaten Karanganyar merupakan sebuah lembaga bisnis yang bergerak di bidang jasa pelayanan kesehatan. Fasilitas pelayanan yang disediakan adalah pelayanan dalam pembuatan tangan dan kaki palsu (Orthotik Prosthetik). Klinik Orthotik Prosthetik Kuspito tersebut merupakan salah satu dari beberapa klinik di Indonesia. Semakin banyaknya jumlah konsumen yang datang untuk mendapatkan pelayanan di Klinik Orthotik Prosthetik Kuspito, dan semakin banyaknya pesaing terutama diwilayah Surakarta, maka penelitian ini diharapkan dapat diketahui gambaran mengenai kualitas pelayanan jasa pembuatan tangan palsu, kaki palsu dan alat bantu mobilitas lainnya yang ditawarkan Klinik Orthotik Prosthetik Kuspito maupun harapan dan persepsi dari konsumennya, serta diharapkan pula didapat suatu informasi sebagai masukan bagi Klinik Orthotik Prosthetik Kuspito dalam rangka perbaikan kualitas pelayanan jasanya guna mencapai kepuasan konsumen, meningkatkan kepercayaan konsumen, mempertahankan dan mengembangkan usahanya. Hasil dari penelitian ini adalah dapat mengetahui penilaian konsumen tentang kualitas pelayanan, serta kepuasan yang dapat dirasakannya. Hal ini penting sebagai acuan dalam pembenahan pelayanan agar dapat memberikan kepuasan yang optimal.

Kata Kunci : Klinik Orthotik Prosthetik, Kualitas Pelayanan, Kepuasan Konsumen 


\section{PENDAHULUAN}

Peningkatan kualitas merupakan salah satu strategi bisnis yang ditekankan pada pemenuhan keinginan konsumen. Di sisi lain, kinerja perusahaan dan kepuasan konsumen merupakan satu kesatuan yang sulit untuk dipisahkan. Kinerja berpengaruh langsung terhadap kepuasan konsumen. Oleh karena itu, suatu unit bisnis diharapkan dapat meningkatkan kinerjanya, dimulai dengan mengetahui sejauh mana tingkat kepuasan yang diperoleh konsumen.

Kualitas juga bagian proses dari inti kelangsungan hidup sebuah lembaga, baik dalam bidang produksi maupun pelayanan. Mengutamakan mutu melalui pendekatan manajemen mutu terpadu menjadi tuntutan yang tidak boleh diabaikan jika suatu lembaga ingin maju dan berkembang, Persaingan yang semakin ketat akhir-akhir ini menuntut sebuah lembaga penyedia layanan jasa untuk selalu memanjakan konsumen/ pelanggan dengan memberikan pelayanan terbaik.

Klinik Orthotik Prosthetik Kuspito Jaten Karanganyar merupakan sebuah lembaga bisnis yang bergerak di bidang jasa pelayanan kesehatan. Klinik Orthotik Prosthetik Kuspito ini mempekerjakan 30 karyawan. Fasilitas pelayanan yang disediakan adalah pelayanan dalam pembuatan tangan dan kaki palsu (Orthotik Prosthetik). Klinik Orthotik Prosthetik Kuspito tersebut merupakan salah satu dari beberapa klinik di Indonesia.

Masalah utama sebagai sebuah lembaga jasa pelayanan kesehatan yang banyak pesaingnya terutama diwilayah Surakarta, diantaranya : Rizki Medika Lestari, Orthomedica, Ortotech, Utama Mandiri, dll. Oleh karena itu, Klinik
Orthotik Prosthetik Kuspito Jaten Karanganyar dituntut untuk selalu menjaga kepercayaan konsumen dengan meningkatkan kualitas pelayanan agar kepuasan konsumennya meningkat. Pihak Klinik Orthotik Prosthetik Kuspito perlu secara cermat menentukan kebutuhan konsumen sebagai upaya untuk memenuhi keinginan dan meningkatkan kepuasan atas pelayanan yang diberikan.

Melihat semakin banyaknya jumlah konsumen yang datang untuk mendapatkan pelayanan di Klinik Orthotik Prosthetik Kuspito, peneliti ingin mengetahui apakah pelayanan jasa yang diberikan klinik Kuspito selama ini telah memenuhi harapan atau keinginan para konsumen, sehingga dirasakan konsumen memuaskan. Dengan kata lain, dengan dilakukannya penelitian ini maka diharapkan dapat diketahui gambaran mengenai kualitas pelayanan jasa pembuatan tangan palsu, kaki palsu dan alat bantu mobilitas lainnya yang ditawarkan Klinik Orthotik Prosthetik Kuspito maupun harapan dan persepsi dari konsumennya, serta diharapkan pula didapat suatu informasi sebagai masukan bagi Klinik Orthotik Prosthetik Kuspito dalam rangka perbaikan kualitas pelayanan jasanya guna mencapai kepuasan konsumen, meningkatkan kepercayaan konsumen, mempertahankan dan mengembangkan usahanya.

Berdasarkan pada pertimbanganpertimbangan tersebut maka perlu dilakukan penelitian yang berprinsipkan pada kualitas pelayanan penelitian ini adalah untuk mengetahui penilaian konsumen tentang kualitas pelayanan, serta kepuasan yang dapat dirasakannya. Hal ini penting sebagai acuan dalam 
pembenahan pelayanan agar dapat memberikan kepuasan yang optimal.

\section{METODE PENELITIAN}

Sesuai dengan tujuan penelitian yang telah dikemukakan di depan, maka penelitian ini menggunakan rancangan atau desain penelitian deskriptif kuantitatif yaitu mixed antara kualitatif dengan kuantitatif untuk mengetahui indeks kepuasan konsumen dari pelayanan di Klinik Orthotik Prosthetik Kuspito Jaten Karanganyar. Tahapan - tahapan yang dilakukan dalam penelitian ini dapat dijelaskan sebagai berikut :

Tahap awal yang dilakukan merupakan observasi lapangan. Pada tahap ini dilakukan studi pendahuluan terhadap obyek penelitian dalam hal ini adalah Pelayanan di Klinik Orthotik Prosthetik Kuspito di wilayah jaten karanganyar, untuk selanjutnya diangkat sebagai tema dan pokok permasalahan yang akan dipecahkan dalam penelitian ini. Tahap ini dilakukan dengan melakukan wawancara dengan pihak Klinik Kuspito maupun pihak konsumen Klinik Kuspito.

Selanjutnya dilakukan tahap studi literature pada tahap ini dikumpulkan berbagai dokumentasi, hasil-hasil penelitian, dan teori-teori yang diarahkan untuk mendapatkan konsep -konsep penelitian yang berkaitan dengan permasalahan yang ada sebagai landasan dalam tahap-tahap penelitian selanjutnya. Teori-teori dan hal penelitian yang memiliki hubungan dengan masalah yang akan diteliti, dijadikan landasan teori sebagai kerangka berpikir untuk menyelesaikan permasalahan yang ada mulai dari tahap awal sampai pada penulisan laporan ini. Landasan teori yang diperoleh dari beberapa literatur merupakan pedoman awal untuk menentukan variabel-variabel penelitian dan memberikan batasan terhadap arah penelitian secara keseluruhan. Dengan dilakukannya studi literatur ini maka diharapkan juga akan meningkatkan nilai dan bobot dari penelitian, jika dibandingkan dengan penelitian yang didasarkan atas pendekatan coba-coba (Trial and error).

\section{HASIL PENELITIAN}

Tabel 1

Karakteristik Responden Berdasarkan Umur

\begin{tabular}{ccc}
\hline Umur & Jumlah & Presentase \\
\hline$<10$ th & 13 & $11.30 \%$ \\
$11-20$ th & 29 & $25.20 \%$ \\
$21-30$ th & 34 & $29.60 \%$ \\
$31-40$ th & 17 & $14.80 \%$ \\
$>50$ th & 22 & $19.10 \%$ \\
\hline
\end{tabular}

Dilihat dari umur pasien, sejumlah $11,30 \%$ (13 orang) telah berumur kurang dari 10 tahun; $25,20 \%$ (29 orang) berumur 11 sampai dengan 20 tahun; $29,60 \%$ (34 orang) berumur 21 sampai dengan 30 tahun; $14,80 \%$ (17 orang) berumur 31 sampai 40 tahun; dan 19,10\% (22 orang) lebih dari 50 tahun.

\section{Tabel 2}

Karakteristik Responden Berdasarkan Jenis Kelamin

\begin{tabular}{ccc}
\hline Jenis Kelamin & Jumlah & Presentase \\
\hline Perempuan & 41 & $35.70 \%$ \\
Laki-laki & 74 & $64.30 \%$ \\
\hline
\end{tabular}

Berdasarkan data diatas, jumlah sampel yang diambil adalah sebanyak 115 orang. Dari 115 orang responden tersebut, diantaranya 74 orang atau $35,70 \%$ dari sampel adalah laki-laki, dan 41 orang atau $64,30 \%$ dari sampel adalah perempuan. 
Tabel 3

\section{Karakteristik Responden Berdasarkan} Pendidikan

\begin{tabular}{|c|c|}
\hline Pendidikan & Jumlah \\
\hline SD & \\
\hline SMP & 36 \\
\hline SMA & 42 \\
\hline Perguruan Tinggi & $17.4 \%$ \\
\hline $\begin{array}{l}\text { Dari dar } \\
\text { gambaran bahy } \\
\text { berpendidikan } \\
\text { berpendidikan } S \\
\text { berpendidikan } S \\
\text { berpendidikan ti } \\
\text { Dari has } \\
\text { yang dilakukan } \\
\text { data yang dapa }\end{array}$ & $\begin{array}{l}\text { ta diatas, diperoleh } \\
4,8 \% \text { (17 orang) } \\
31,3 \% \text { (36 orang) } \\
36,5 \% \text { (42 orang) } \\
17,4 \% \text { (20 orang) } \\
\text { t perguruan tinggi. } \\
\text { enyebaran kuisioner } \\
\text { lanjutnya diperoleh } \\
\text { olah secara statistik } \\
\text { entu, dengan rincian }\end{array}$ \\
\hline
\end{tabular}

\section{Tabel 4}

\section{Rekapitulasi Penyebaran Kuisioner}

\begin{tabular}{clc}
\hline No. & Keterangan & Jumlah \\
\hline 1. & $\begin{array}{l}\text { Kuisioner yang dapat diolah } \\
\text { / kembali }\end{array}$ & 110 \\
2. & $\begin{array}{l}\text { Kuisioner yang tidak dapat } \\
\text { diolah (Pengisian yang }\end{array}$ & 9 \\
$\begin{array}{l}\text { kurang lengkap) } \\
\text { Kuisioner yang tidak } \\
\text { kembali }\end{array}$ & 31 \\
\hline & & 150 \\
\hline
\end{tabular}

Dari tebel diatas diketahui bahwa

sejumlah 9 kuisioner dinyatakan tidak dapat diolah, dari 9 kuisioner yang belum lengkap pengisiannya tersebut. Selanjutnya dilakukan konfirmasi ulang kepada responden untuk melengkapi pengesian kuisioner yang bersangkutan untuk selanjutnya diolah bersama dengan 110 kuisioner yang sebelumnya sudah terkumpul. Dari hasil konfirmasi ulang hanya 5 kuisioner yang kembali sementara 4 kuisioner tidak kembali sehingga total kuisioner yang diolah berjumlah 115 buah.

\section{PEMBAHASAN}

Analisis pengolahan data umum responden meliputi data karakteristik responden/ pasien yang terdiri dari jenis kelamin, tingkat pendidikan, dan usia yang dikaitkan dengan tingkat kepuasan konsumen di Klinik Kuspito yang akan diuraikan lebih lanjut sebagai berikut:

Berdasarkan data yang diperoleh dari responden pengguna di Klinik Kuspito jaten karanganyar, hasil penyebaran kuesioner mengidentifikasikan bahwa pengguna pelayanan di Klinik Kuspito didominasi oleh kelompok usia 21 hingga 30 tahun, terbukti dari data pada tabel 4. yang menunjukkan jumlah pengguna berusia 21 hingga 30 tahun mencapai 34 orang dari total 115 responden. Usia 21 hingga 30 tahun tergolong dalam usia produktif, dimana individu tergolong dalam angkatan kerja. Pada usia produktif kegiatan atau aktivitas manusia cenderung tinggi, sehingga tingkat kecelakaan kerja juga tinggi, walaupun tujuan pelayanan tidak hanya untuk golongan usia tertentu, namun pada faktanya akan lebih dibutuhkan bagi individu yang masih aktif bekerja.

Berdasarkan

penyebaran kuesioner, pengguna pria lebih banyak dibandingkan dengan pengguna wanita, yaitu dari 115 pengguna pelayanan di Klinik Kuspito, 74 diantaranya adalah pengguna pria dan pengguna wanita hanya 41. Pelayanan di Klinik Kuspito ini tidak bertujuan untuk golongan jenis kelamin tertentu. Pria cenderung tidak memperhatikan atribut yang berkaitan dengan biaya pelayanan dibandingkan dengan wanita, selain itu atribut biaya 
pelayanan menduduki peringkat ke-19 pada urutan tingkat kepuasan pengguna, sehingga biaya tidak menjadi prioritas utama dalam pelayanan di Klinik Kuspito.

Dari sisi pendidikan responden yang dikategorikan menjadi empat tingkat pendidikan yaitu SD, SMP, SMA, dan Perguruan tinggi. Berdasarkan hasil penyebaran kuesioner, pengguna pelayanan di Klinik Kuspito didominasi oleh kelompok pendidikan tingkat SMA, terbukti dari data pada tabel 4.5 yang menunjukkan jumlah pendidikan SMA mencapai 42 orang dari total 115 responden. Pendidikan tingkat SMA yang ada di Klinik Kuspito adalah kebanyakan lulusan SMA yang sudah selesai pendidikan langsung bekerja tidak meneruskan ke perguruan tinggi.

Dari hasil perhitungan terhadap tingkat kepuasan konsumen terhadap kualitas pelayanan kesehatan berdasarkan tingkat kesesuaian di Klinik Kuspito jaten, karanganyar, mayoritas konsumen dilihat dari kinerja terdapat sejumlah $1,6 \%$ dari seluruh responden menyatakan bahwa sangat jelek dengan pelayanan yang mereka terima, sejumlah $42,4 \%$ dari responden menyatakan jelek, $28,9 \%$ dari responden menyatakan mereka merasa biasa dengan pelayanan yang selama ini diberikan oleh Klinik Kuspito, 10,4\% menyatakan baik dan sejumlah 16,7\% mereka menyatakan sangat baik.

Sedangkan bila dilihat dari segi harapan konsumen sejumlah $12.5 \%$ dari seluruh responden menyatakan bahwa mereka sangat puas dengan pelayanan yang selama ini mereka terima, sejumlah $54.0 \%$ dari responden menyatakan mereka merasa puas dengan pelayanan, $19.9 \%$ dari responden menyatakan biasa, $6.8 \%$ menyatakan tidak puas dan sejumlah $6.8 \%$ mereka menyatakan sangat tidak puas.
Dari urain hasil diatas, berdasarkan keluhan mayoritas responden bisa diambil kesimpulan bahwa pelayanan di Klinik Kuspito bila dilihat dari kinerja dinyatakan jelek. Namun bila dilihat dari harapan menyatakan pelayanannya memuaskan.

\section{KESIMPULAN DAN SARAN}

Hasil penelitian mengenai analisis kepuasan konsumen terhadap kualitas pelayanan klinik orthotik prosthetik kuspito jaten karanganyar, dapat disimpulkan sebagai berikut : (1) Tingkat kepuasan konsumen terhadap kualitas pelayanan di Klinik Kuspito, menunjukkan bahwa nilai skor kinerja sebesar 347,6 sedangkan nilai skor harapan konsumen terhadap kualitas pelayanan sebesar 412,3. Hal ini berarti harapan konsumen lebih tinggi dari pada kenyataan empirik yang dapat dilakukan oleh klinik kuspito dalam melayani konsumennya, (2) Ditemukan ada ketidaksesuaian antara kinerja kualitas pelayanan dengan harapan kualitas pelayanan. Kenyataan ini merupakan kewajaran yang terjadi hampir disemua institusi. Meskipun demikian untuk menentukan perlu dan tidaknya dipertahankan sebuah pelayanan ditentukan berdasarkan pada posisi kuadran., (3) Berdasarkan dari posisi kudran, dapat diketahui bahwa menurut responden yang mempengaruhi penilaian mereka terhadap kualitas pelayanan di Klinik Kuspito antara lain : Prosedur pelayanan, kejelasan petugas pelayanan, kecepatan pelayanan, kepastian jadwal pelayanan dan keamanan pelayanan.

Saran dari penulis mengenai penelitian berdasarkan kesimpulan diatas adalah: (1) Seiring kemajuan jaman, Klinik Kuspito perlu lebih meningkatkan 
mutu pelayanan baik dari SDM, sarana prasarana dan lebih meningkatkan promosi ke masyarakat, (2) Dari saran konsumen, Klinik Kuspito diharapkan untuk mempercepat perbaikan terhadap adanya gangguan dan kerusakan yang terjadi. Hal ini mungkin dapat diatasi dengan penambahan alat atau cek ulang alat - alat yang digunakan/ service, (3) Saran lain yang muncul dari konsumen antara lain mengenai peningkatan ketrampilan Hal ini bisa diatasi dengan cara memberikan pelatihan - pelatihan yang berhubungan dengan keahliannya masing - masing.

\section{DAFTAR RUJUKAN}

Kepmen PAN No. 63/M.PAN/7/2003 tentang Pedoman Umum Penyusunan Indeks Kepuasan Masyarakat Unit Pelayanan Instansi Pemerintah.
Kepmen PAN No. 25/M.PAN/2/2004 tentang Pedoman Umum Penyusunan Indeks Kepuasan Masyarakat Unit Pelayanan Instansi Pemerintah.

Keputusan Menteri Pendayagunaan Aparatur Negara Nomor 81 Tahun 1993 Tentang Pedoman Tatalaksana Pelayanan Umum

Kotler, P. (2003), Marketing Management: Analysis, Planning, Implementation, and Control, $13^{\text {th }}$ edition. Englewood Cliffs, NY: Prentice-Hall, Inc

Sevilla, G.S. dkk. (1993). Pengantar Metodologi Penelitian. Jakarta: Universitas Indonesia-Press 